\title{
GESTURES, DANCE AND COLOUR: NON-LINGUSITIC COMMUNICATION IN EMOBO AND EWERE CELEBRATIONS IN BINI KINGDOM OGUNDUYILEABIMBOLA
}

General Studies Department, Federal University of Technology, Akure, Ondo, Nigeria

\begin{abstract}
While language is one important means of re-enacting the history and culture in festivals, it is not the only means; the use of gestures, dance and colours has been greatly maximised in Ugies (festival or celebration) Emobo and $E$ were. They are festivals, whose central figure are the Oba and depict two memorable events in the lives of the Obas of the past, and they are celebrated yearly to commemorate these occasions. The work focuses on the use of gestures, dance and colour, which are replete in these performances to foreground the message of these festivals, and how these nonlinguistic cues have been used to re-enact the history of the Bini people and the Obas in particular. This paper is anchored on the semiotics theory, which deals with the study and analysis of signs and symbols as part of communication for the effective execution of these festivals. It is discovered from the analysis that these non-linguistic cues are very important in execution of the festival because they aid in complete understanding of the festival.

KEYWORDS: Ugies, Emobo \& E were
\end{abstract}

Received: Jul 20, 2017; Accepted: Aug 08, 2017; Published: Aug 21, 2017; Paper Id: IJELAUG201725

\section{INTRODUCTION}

Festivals in Africa are a way of life. Selase (2013) describes festivals as "manifestations of the practices and beliefs of a people. They are promoters of culture and builders of one's identity. Festivals perform many functions in the society. They serve as a means of commemorating and remembering important events in the history of a people. In the process, they perform other functions, both intended and unintended. As they involve recreation of the past, they provide occasions for transmission of traditional cultures and values from one generation to the other Among the Bini. Among the Yoruba, Sango, Ogun, Osun, Oya are mythical figures and festivals are designed to remember the epochal lives they lived and the contributions they made to the various Yoruba communities

The Ugies (which means festivals) Emobo and Ewere are festivals that marked an important history in the lives of the Obas of Bini. They tell of the problems and eventual victory of the Obas in different times of Bini history in Edo State, these festivals are historical. The Emobo Celebration in the Igue Festival commemorates the success of Oba Esigie's victory over his brother the Enogie of Udo, Arhuanran, in the Edo-Udo war. The Emobo Festival dates back to the history of the death of Oba Ozolua in Esan. His two sons, Osawe and Idubo (Arhuanran the giant of Udo) contested for the throne because the Binis refused to allow the eldest son of Ozolua, Ogidogbo to ascend the throne because, he was crippled due to the fracture he sustained during an exercise of pole jumping over the pond of Agbodo, as a demonstration of his strength in a contest with his two younger brothers. Prince Osawewas later crowned Oba Esigie, but his brother Arhuaran would not give him peace and a fight ensued between both of them until Esigie defeated Aruanran and in despair Aruanran drowned himself in the lake Odighi 
n' Udo.

The UgieEwere is a festival, which is done in the early hours of the day by presenting Eb'were leaves to the Oba. These leaves symbolise joy and prosperity. According to Izevbigie, The Festival was first celebrated during the reign of Oba Ewuare in about 1440AD to celebrate his prosperous wedding with Ewere, a peaceful woman after he had suffered a turbulent marriage with Ubi, a troublesome woman.

These festivals along with other festivals are a culmination of the festival 'Igue'. Igue Festival is one of the major festivals celebrated by the people of Benin Kingdom in Edo State in Benin. This festival is celebrated at the end of one year to usher in a new year. Igue emphasises the ritual of head worship. There are two reasons for this worship. First, as the head is regarded as the essence of personality, it must be kept in good condition, so that, it may be well with the person. Secondly, one must be on good terms with it, so that it may favor one. To the Bini man, it is the head that takes you through life journey. The head must be good to perform this life's journey. (IyiEweka). This is similar to the concept of Ori amongst the Yoruba, where the head is also considered to be the bringer of good or evil (Balogun, 2007)

The main focus of praise or the central focus in most of the festival is the Oba. Throughout the festival, it is common and expected that from time to time the cry "Oba atokpee" is chanted by the chiefs or the audience and the people reply "Isee" meaning "Long live the King" "Amen".

\section{Non-Linguistic Communication}

Nonlinguistic or nonverbal communication, according Mehrabian (1990) in Tiswari (2105) represents "two thirds of all communication". According to Stevick (1982:163), "If verbal communication is the pen which spells out details, nonverbal communication provides the surface on which, the words are written and against which they must be interpreted." In situations where, there is conflict between the words said and the feelings expressed, people tend to put more faith in the latter because of its ability to make intentions or meanings of the speaker much clearer. Sarah and Arthur (1976) note that "non verbal codes are given more credence and are more trusted than verbal codes". This is attributed to the fact, nonverbal communication is learned shortly after birth and practiced and refined throughout a person's lifetime.

These nonlinguistic forms of communication can be visual, aural or gestural which speak more directly and clearly than words, because words have their limitations (Sharma, 2013). Nonverbal codes are gestures which include body language or posture, facial expressions; eye contact; object communication such as clothing, hairstyle or even architectural designs; the use of space, time and even silence. Speech(verbal) may also contain nonverbal elements known as paralanguage, including voice quality, emotions and speaking style, as well as prosodic features for example rhythm, intonation and stress(see Pennycock 1958). Likewise, written texts have nonverbal elements such as handwriting style, spatial arrangement of words, or the use of emoticons.

Culture determines to a very large extent the meaning of nonverbal codes. For example, among the Bini people, white is commonly regarded as a colour of purity while among the Indians and the Igbos, it is a colour of mourning. Northern Europeans usually indicate agreement by nodding their heads up and down, and shaking the head from side to side to indicate disagreement. The Greeks have for at least three thousand years used the upward nod for disagreement and the downward nod for agreement (Kirch, 1978). In other words, each culture has its peculiar way of interpreting non-verbal codes, the meaning of a particular gesture in one culture may mean something completely different in another culture. Non verbal codes have been classified severally by different scholars Knapp and Hall (1972), Argyle (1972), Pearson et al 
(2006).The nonverbal codes can be classified into nine broad categories, which are: Chronemics, Kinesics, chromatics, proxemics, objectics, Tactile (haptics), osculies, silence and paralanguage.

Chronemics: This is the study of time and, how it affects communication. The way time is perceived, structured and reacted helps set the stage for the communication process. Time perceptions include punctuality, willingness to wait, and interactions. The use of time can affect lifestyles, daily agendas, speed of speech, movements and how long people are willing to listen; it also tells a lot about personalities. Chronemics also indicates status and power.

Kinesics: This category covers a wide range of non verbal codes ranging from gestures, facial expressions, body movements, postures.

Proxemics: This was introduced by E.T. Hall, when he investigated man's use of personal space within context of culture. Hall(1973) defines proxemics as “the study of man's transactions, as he perceives and uses intimate, personal, social and public in various settings, while followings out of awareness dictates of cultural paradigms". Proxemics can be seen from two angles. They are; territoriality and personal space

Chromatics: Chromatics is a communication of messages through colours and how colours are viewed by different societies.

Objectics: It is also referred to as object language. This is the study of human use of clothing and other artefacts as nonverbal codes. Artefacts are ornaments, jewellery, hairstyle, automobiles, buildings, shoes, portfolios, tattoos, body piercing, and even teeth fillings (Pearson et al 2006).

Haptics: This nonverbal code is the means by which, people and other animals communicate via touching. Touch is an extremely important sense for humans because, it involves invasion of another's personal space: Functional/professional; Social/polite, Friendship/warmth, love/intimacy; sexual/ arousal.

Osculies: This is the study of eye contact, an event in which, two people look at each other's eyes at the same time.

Paralanguage: Non verbal codes also include sounds which are not words. Pennycock (1985) defines it as those "non lexical aspects of speech communication, largely characterized by distinguishable degrees of intensity, velocity, extent and duration of pitch fluctuation, duration of utterance segments, and the use of sounds not occur-ring in the standard language system

Silence: Silence sends volumes of meaning in communication and like other nonverbal code is perceived negatively or positively, depending on the social context in which it is used.

\section{THEORECTICAL FRAMEWORK}

This study is anchored on the theory of semiotics. Semiotics, the study of signs and the meaning understood from these signs, was derived from the Greek word "semeiotikos", which means the observance of signs which also has its roots from another Greek word "semeion", which was coined by the philosopher John Locke in the early 17th century. The Oxford Companion to the English Language (1996:835) defines semiotics as "the study and analysis of signs and symbols as part of communication, as for example in language, gesture, clothing and behavior". Roland Bathes observes that semiotics attempts to account for "any system of signs whatever their substances" and this may include Eco (1976: 9-13) 
"many different areas of research, such as: zoosemiotics (including the study of animal communication), paralinguistics (including the study of how voice control or vocal qualities may contribute to communication), kinesics and proxemics (including the study of how physical gestures or postures may contribute to communication), tactile communication (including the study of how behavior such as a pat on the back or a slap on the shoulder may function as a mode of communication), visual communication (including the study of how photographs, drawings, maps, or diagrams may function as modes of communication), medical semiotics (including the study of medical signs and symptoms), text theory (including the study of literary texts), and the study of rhetoric, the study of ancient alphabets and secret codes, the study of formalised languages (including the study of mathematical, logical, or scientific languages), the study of natural languages (including biological and environmental signs), the study of olfactory signs, the study of codes of taste, the study of musical codes, the study of systems of objects (including the study of architecture and of industrial design), the study of cultural codes (including the study of group and family behavior), and the study of mass communication (including the study of media such as television, newspapers, magazines, and film).”

These signs, in their relation to each other to derive their meaning, depend on the code within which they are situated. Codes provide a framework within which signs make sense. Codes are not simply 'conventions' of communication but rather procedural systems of related conventions which operate in certain domains. The status of a sign cannot be granted if it does not function 1within a code. Furthermore, if the relationship between a signifier and its signified is relatively arbitrary, then it is clear that interpreting the conventional meaning of signs requires familiarity with appropriate sets of conventions. Codes transcend single texts, linking them together in an interpretative framework. (Heath (1981, 130)) notes that 'while every code is a system, not every system is a code' since the meaning of a sign depends on the code within which it is situated, codes provide a framework within which signs make sense. Codes help to simplify phenomena in order to make it easier to communicate experiences (Gombrich 1982:35). When studying cultural practices, semioticians treat as signs any objects or actions, which have meaning to members of the cultural group, seeking to identify the rules or conventions of the codes which underlie the production of meanings within that culture. Understanding such codes, their relationships and the contexts in which they are appropriate is part of what it means to be a member of a particular culture. In conclusion, semiotics allows for the study of signs and the codes in which these signs derive meaning, putting into cognizance the cultural setting in which they are used.

\section{GESTURES, DANCE AND COLOURS AS NON-LINGUISTIC COMMUNICATION}

Gestures are types of body movements or kinesics involving the physical movement of the body. They help to express thoughts and/to emphasise one's speech. Ekman and Freisen identified five:

Emblems: These are substitutes for verbal language. Adedimeji (2006:191) describes emblems as body movements and gestures which have specific equivalents in certain cultures and societies

Illustrators: They aid verbal language. These are used to accompany what is being said (Adedimeji, 2006:190).

Regulators: These are acts that maintain and regulate the act of speaking. They are also non-verbal signs that regulate, modulate and maintain the flow of speech during a conversation.

Displays: These are body, or more frequently facial, movements that display a certain affective state, that is, emotions. They are unconscious behaviours borne out of heightened emotional arousal (O'Hair 1995, Oyewo 2000:101)

Adaptors: Adaptors include postural changes and other movements at a low level of awareness frequently made 
to feel more comfortable or perform a specific physical function.

Emblems and illustrators are greatly used in these festivals.

Dance: According to Hanna (2008), "dance can be conceptualised as human behaviour composed of purposeful, intentionally rhythmical, and culturally influenced sequences of nonverbal body movements and stillness in time and space and with effort. Dance is usually accompanied by music, with its range of sounds and rhythm, and sometimes by costume and props. Dance may bea vehicle, or an open channel, for purposeful communication. Effective communication, of course, depends on the shared knowledge between dancer and audience. There is also another nonverbal code that is prominent with dance. This code is kinesics, which includes facial movements and eye contact/gaze. These codes can also be called immediacy cues".

Dance can be contextualised and greatly influenced and explained through culture. Culture gives meaning to who dances what, why, how, when, where, and with and for whom, in addition to the role of the dance audience. Such variables may bespeak sexual orientation and gender roles, as well as ethnic, national, and other group identities. These may promote self-esteem, separatism, or nationalism.

This nonverbal communication is used in these festivals to enact the history of past events in the lives of the Obas.

Colours: Colours mean different things in different cultures, what a colour means in America could mean something else in Africa or Asia. The connotations which colours have may be negative or positive depending on the culture. For example, white is used for mourning in India while in North America, it is the colour used in weddings. In Chile, yellow roses mean 'I do not like you' while it means the opposite in America.

In these festivals, these nonverbal cues are replete during these performances and will be studied in detail.

\section{UGIE EMOBO}

This festival dates back to the history of the death of Oba Ozolua in Esan. His two sons, Osawe and Idubo (Arhuanran the giant of Udo) contested for the throne because, the Binis refused to allow the eldest son of Ozolua, Ogidogbo to ascend the throne since he was crippled. Osawe, eventually won the contest and was crowned Oba Esigie. The festival is to re-enact his victory over Arhuanran.

UgieEmobois celebrated outside the palace gate. The king sits in a pavilion of red cloth where rites are performed to drive away all evil spirits still unsatisfied by the year's sacrifices. There are no sacrifices in Emobo festival or appearances by the Oba's wives and children. The Oba sits in a specially constructed pavilion made of red cloth - -being a 'threatening' colour (ododo) one with capacity to drive away evil spirits. The Oba puts on his red/scarlet ceremonial robe, holds ivory gong/bell with other ivory pendants and carved ivory bracelets (Ikoro). The ivory gong which the Oba strikes when dancing at ugieEmobo is to drive away evil forces. The white ivory gong is very special in this ceremony, because it reflects the ritual purity and ideal state to which Emobo festival entails. While the Oba holds his gong, Chief Isekhurhe holds the shrine staff (Ukhurhe) Chief Esogban, Ihaza` and others dance round, while the drummers of Ogbelaka IkpeEwini beats the traditional drum and supply the music.

Chief Esogban, the Odion were of Benin performs his rite. He dramatically dismisses the evil spirits by calling on Edo, Uselu, Uzebu and all gods to leave Benin City and go to Udo town in Iyekogba, where they may find food. He prays for the Oba and the entire Kingdom. When he is done, The Esogban goes home and without looking back. The Oba walks 
to the drummers and personally strikes the drum to start off the music for his dance. Isekhurhe and Obamwonyi of Ogbelaka join the Oba and dance around the drummers. This period is the only time the Oba dances before the people. As the dancing continues, the Oba dance to the location adjacent to the Edion shrines, raises the Ukhurhe (ancestral staff) and Eben (ceremonial sword) and pray that all evils be driven out of the Benin Kingdom. After praying, the Oba, accompanied by Isekhurhe, Obamwonyi, other chiefs and functionaries dance into the palace while Ogbelaka group still supplies Ewini traditional music. As the Oba returns to the palace, he stops four times and faces the drummers who sing incantations on his return journey into the palace. The Oba at this time no longer plays the ivory but tosses the strand of beads that run dorm from the sides of his crown.

\section{Gestures}

During UgieEmobo, the specific body movements significant to this celebration are:

\section{Salutations}

- This is seen in the gestures of the court jester, who turns his fan made of skins and constantly bows.

- Another instance of greetings in the festival is, when the Esogban (the keeper of the Elder's shrine) dances with the musicians of the Ogbelaka group. The Esogban, each time he dances round knots his right hand into a fist and hit it with his open left hand and raise the fist into the air.

\section{Prayers}

This gesture complements the prayers of the Isekurhe. After the dance of the Oba, the Isekurhe stands opposite the Oba who backs the Ozolua Statue and the Isekurhe prays for the Oba and as he does so, he stamps his staff on a rock, this is like a seal on the proclamations and prayers he has previously offered.

\section{Colours}

Throughout the festival, certain colours carry some significance to the people. These are the colours red (scarlet), white and brown. The colour red meaning 'ododo' is a symbol of power and authority. The Oba also uses this colour to indicate his displeasure over issues or his victory over battles. This is specially seen in the UgieEmobo. The Oba wears red as a sign of war and victory to depict the war and subsequent victory of the Oba over his brother the Enogie of Udo, Arhuanran the giant.

The brown colour is used by the 'ifieto' and the palace servants called 'omoada'. The brown colour is symbol of service and lowliness. The history of the ifietos date back to AD 1660. When prince Odogbo also called Ohuan was growing up; he was very handsome and very girlish in appearance that people thought he was a girl. When his father Ehengbuda heard of it, he told his Ohuan to work naked from Benin to Uselu. The Prince and his servants (who were also naked) had their hair well cut and dressed for the occasion and began their unusual procession. Thus, Odogbo was seen to be a man. The Prince and his attendants were called 'ifieto' meaning 'hair curlers' see Egharevba(1956). The term 'ifieto' survived to this day and they are seen preceding the royal procession and sometimes acting as security during celebrations. The omoada or 'swordbearers' are servants, who attend to the needs of the Oba. They are also seen in scarlet and brown outfits which tell that they are servants of royalty.' 


\section{Dance}

Some celebrations in Igue are solemn, but some are full of gaiety and such employ the use of dance as a way of entertainment and also a way of re-enacting past heroic deeds. In UgieEmobo, there are two dances: First, is the dance of the Esogban of Benin(one of the four cardinal chiefs of the Benin Kingdom) and the Ogbelaka group. The dance tells of an event which happened in history. Emobo is the preserve of the bards (ogbelaka) who perform seven perform seven different songs and seven different dances, all of which re-enact Esigie's insanity on the road from Udo (He claimed a chest of superior corals bead, which aided Arhuanran in his wars and which he cursed that anyone who wore it, would run mad (Esigie wore it and ran mad, but was quickly cured). The second dance is the dance of the Oba. This is the only time the Oba dances in public. He dances to seven different songs, all enacting Esigie's insanity on the road from Udo.

\section{UGIE EWERE}

According to Izevbigie, The Festival was first celebrated during the reign of Oba Ewuare in about 1440AD. During this period, there lived a chief called Ogieka, who had three beautiful daughters; Ubi, Ewere and Uyoyo. The news of their beauty got to Ewuare and he asked to Ogeika to marry his eldest daughter to him, and Ogieka replied that Ewuare could not marry his daughter, because she was shrewish and disrespectful. However, the king's command was law.

Although Ubi was reluctant, there was nothing she could do; so she was taken to the Oba's palace. On reaching the palace, she was unfriendly to the other wives and maids in the harem. The Oba tried everything he could to tame her of her shrewishness, but she would not be tamed. Ubi in other to be sent away from the palace started urinating in the house and this was forbidden in the palace. The Oba then ordered her to be driven away from the palace.

Then days later, Ewuare asked Ogieka to send Ewere in replacement of Ubi. Ogieka agreed and on the day Ewere was brought to the harem, the Oba ordered 'Ihogba' to escort her and the 'Osuma' to wait on her and honour her entry into the palace. Ewere was accepted warmly because; unlike her sister she acted humbly and honourably. As a result, she was loved by the Oba and the women in the harem. About a week after Ewere entered the harem, she began to think of her sister, Oyoyo, and she cried every day. Oba Ewuare again sent a message to Ogieka, asking him to allow Oyoyo to visit her sister. This request was promptly granted by Ogieka, and Ewere was very pleased to see her sister, and was not willing to let her sister return home so Ewuare decided to marry her as well. So the two sisters became wives of the Oba.

When Oyoyo became pregnant, the Oba sent her to the Ihama at Idunmwihogbe for proper care and there she gave birth to a daughter. As a token of his gratitude, the Oba awarded the Ihama the Odibokofo (a large collar made entirely of red beads) and gave his wives the right to dress their hair in the Ukpokhokho style, like the Oba's wives. This elevated the Ihama to a higher position than ever before, and the Odibokofo has been worn by every Ihama at every Ugie-Ewere ceremony till date. Throughout his reign, every year the Oba celebrated UgieEwere, that is the anniversary of his happy and prosperous marriage to Ewere at the Igue festival by sacrificing goats, cows, kolanuts and coconuts to his head for giving him good luck throughout that year.

\section{GESTURES}

\section{Salutation}

- Before the Oba's public appearance in each celebration, the chiefs converge in front of his inner chamber and as he stands before them, they knot their right hand into a fist and hit it with their open left hand and raise the fist into the air, chanting 'Oba aton pa e' meaning 'may the king live long'. This gesture is an emblem used to salute 
the king and its meaning is derived from the culture of the people.

- Another form of salutation is seen, when the King extends the 'eben' to the Ozolua statue on his way out of his inner chambers. Just as the Oba is recognized as king and divine, the Oba also acknowledges the ancestors as divine. This is common with most African traditions, just as the people recognizes and pay obeisance to the King, he also must accord some respect to his ancestors who, without their support, cannot ascend the throne.

- The people also greet the Oba by kneeling before him. Only titled chiefs can stand before the Monarch to greet or salute him.

\section{Supplication}

- The chiefs, after raising their fists to the air, rub their palms together as a sign of supplication to the Oba.

- The Oba, before the commencement of each day's festival, taps a black metal gong and then a white metal gong as way of invoking the ancestors to come and be a part of the ceremony.

In the course of the celebration, after every chief is given kola nut, the Oba sends one kola nut to the head of the Edion or Uzama and of the EghaevboN'Ore. They break open the kola nut, place on the ground and pour water on it. This is a form of libation to the ancestors.

These gestures are however not unique to the Ewere Festival, it is common in all the Ugies celebrated during the Igue festival.

\section{Dance}

The use of dance in UgieEwere as a very important non verbal communication is seen in the performance of Osuma, in presenting the mascot to the Oba during the Igue Festival. The dance is performed to re-enact the loyalty of a servant Avan to Oba Ewuare. As Eweka 1992 records, when Ewuare waged war on a certain people on the eastern part of the empire, he forgot his mascot at the village he fought. It was believed that if the enemies got hold of the mascots, they would eventually defeat Ewuare. One of the servants, Avan volunteered to return to the village to retrieve the mascot, Avan was however caught but he managed to get hold of the mascot and he hid it under his clothes. He remained a captive for years and eventually sold as a slave. He was sold to a chief in Benin. His master then decided to use him as a sacrifice and went to ask for permission from the Oba. Avan was gagged by this time but he made frantic efforts to speak. The king noticing him ordered his release, so that he speaks. Avan drew the attention of the Oba to the past event and the Oba, pleased, ordered his release and conferred on him the title Nayasuma(my confidant),hence the origin of the Osuma title. At each UgieEwere, this noble event is re-enacted. Dance is also used as a non verbal communication to re-enact the success of the old man in bringing the Igue leaves from Uhe( Ife). It was said that Oba Ewuare was undergoing some domestic crises and it was said that a certain leaf would and bring an end to his travails. The leaf was reputed to be in Ife. This leaf was eventually brought the Ewuare, who at that time married a woman called Ewere. The Ayobahan, in his dance during the UgieEwere re-enacts the event of bringing the leaf from Uhe/Ife. UgieEwere is a celebration of goodwill and a time. The Ihogbes (the king's priests) led by the Chief Isekurhe dances, as they present the Oba with the leaf of good luck. This is a dance of good will and of prayers. It is also meant to entertain the king and his guests during the Igue Festival. 


\section{Colour}

The Oba wears red during the UgieEwere. UgieEwere is often mistaken as the Igue Festival by outsiders but in reality, it is the last major festival in the series of the Ugies celebrated. It is a day, people come out en masse to greet the Oba, and it is therefore in place for the Oba to wear red which is the symbol of his authority as the Oba of the Kingdom. The colour red depicting royalty, authority is opposed to some cultures that use purple instead as a symbol of royalty.

\section{CONCLUSIONS}

The UgieEmobo and UgieEwere celebrated by the Bini people are very revered and important celebrations in the Igue festival. These festivals have preserved the history, which has affected and sharpened the lives of the Bini people. The festival, however, due to modern times has been in several ways modified to suit the present age, but some aspects of it which are important are still guarded so as not to lose the essence of the festival. The festival like every endeavour of man can only be made possible by the use of language and language includes nonverbal cues. The nonverbal aspects of these Ugies go a long way in explicating the aim of the festival; they aid the observer in understanding the meaning of these celebrations. The meanings of the signs used are interpreted in the culture of the people, therefore in understanding these signs; one to a very large extent understands the values, beliefs and lifestyle of the Bini people. This leads to fully appreciating this festival, which is a very rich aspect of the culture of the people

\section{REFERENCES}

1. Adedimeji, M. 2006: Non verbal Semantics: Meaning in English. Ed A. OdebunmiLautech: Critical Sphere.

2. Ashish, K.T. 2015. Non-Verbal Communication-An Essence of Interpersonal Relationship At Workplace. School of Management Journal Vol. XI, No. 2

3. Birdwhistell, R.L.1970. Approaches to Semiotics. Ed. Sebeok, Thomas A. et al. The Hague/Paris: Mouton

4. Ekman and Freisen W.V.1971. Constants across Cultures in the face and Emotion. Motivation and Emotion. 10 159-168.

5. Eweka,E.B.1992.Evolution of Benin Chieftaincy Titles. Edo: Uniben Press.

6. Hanna, J.L. 2008. A Nonverbal Language for Imagining and Learning: Dance Education in K-12 Curriculum. Educational Researcher, Vol. 37, No. 8, pp. 491-506.

7. Iyi-eweka, A. Igue Festival. http://www.edofolks.com..

8. Jenkins M and Randall D. 1977. What an Information Analyst should know about Body Language. MIS Quarterly, Vol. 1, No. 3, pp. 33-47. Management Information Systems Research Centre, University of Minnesota. http://www.jstor.org/stable/248711

9. Kendon, A.1997. Gesture. Annual Review of Anthropology, Vol. 26 (1997), pp. 109 128.Annual Reviews. http://www.jstor.org/stable/2952517

10. Kirch M. 1979.Non-Verbal Communication across Cultures. The Modern Language Journal, Vol. 63, No. 8. Blackwell Publishing. http://www.jstor.org/stable/326027

11. Omoigui, N. History of Igue Festival in Benin-City.http://www.edofolks.com.

12. Peick, M. 2005 Dance as Communication: Messages Sent and Received Through Dance: UW-L Journal of Undergraduate Research VIII.

13. Pennycook, A. 1985.Actions Speak Louder than Words: Paralanguage, Communication Journal and Education Source: TESOL Quarterly, Vol. 19, No. 2.pp. 259-282.Accessed:14/04/2008. 06:29. http://www.jstor.org/stable/3586829 
14. Selase, G.R. 2013. The Socio-Economic Benefits derived from Festivals. A Case Study of Asogli Yam Festival In Ghana. International Refereed Research Journal. Vol.- IV, Issue - 4, Oct. 2013 [64]

15. Sharma, P.B. 2013: Bharatanatyam: The Crescendo of Non Verbal Communication. IMPACT: International Journal of Research in Humanities, Arts and Literature (IMPACT: IJRHAL)ISSN 2321-8878. Vol. 1, Issue 5, Oct 2013, 13-22

16. Umberto Eco 1981. The Theory of Signs and the Role of the Reader: The Bulletin of The Midwest Modern Language Association, Vol. 14, No. 1, pp. 35-45. Midwest Modern Language Association. http://www.jstor.org/stable/1314865

17. Umberto, E. 1976: A Theory of Semiotics. Bloomington: Indiana University Press.

18. Uyilawa U, Falola, T and Egharevba, J.1998. A Comparison of Jacob Egharevba's "EkhereVbItan Edo" and the Four Editions of Its English Translation, "A Short History of Benin": History in Africa, Vol. 25. pp. 361-386.African Studies Association Stable. http://www.jstor.org/stable/3172194 Accessed: 25/10/2008 08:53

19. Walker, J.A.1977. Comments on Umberto Eco's Book "A Theory of Semiotics. "Leonardo, Vol. 10, No. 4 pp. 317-319. The MIT Press. http://www.jstor.org/stable/1573772. 